\title{
New investment, old challenges. Land deals and the water constraint in African agriculture
}

DOI:

10.1080/03066150.2012.660481

\section{Document Version}

Accepted author manuscript

Link to publication record in Manchester Research Explorer

\section{Citation for published version (APA):}

Woodhouse, P. (2012). New investment, old challenges. Land deals and the water constraint in African agriculture. Journal of Peasant Studies, 39(3-4), 777-794. https://doi.org/10.1080/03066150.2012.660481

\section{Published in:}

Journal of Peasant Studies

\section{Citing this paper}

Please note that where the full-text provided on Manchester Research Explorer is the Author Accepted Manuscript or Proof version this may differ from the final Published version. If citing, it is advised that you check and use the publisher's definitive version.

\section{General rights}

Copyright and moral rights for the publications made accessible in the Research Explorer are retained by the authors and/or other copyright owners and it is a condition of accessing publications that users recognise and abide by the legal requirements associated with these rights.

\section{Takedown policy}

If you believe that this document breaches copyright please refer to the University of Manchester's Takedown Procedures [http://man.ac.uk/04Y6Bo] or contact uml.scholarlycommunications@manchester.ac.uk providing relevant details, so we can investigate your claim.

\section{OPEN ACCESS}




\title{
New investment, old challenges. Land deals and the water constraint in African agriculture.
}

\author{
P Woodhouse
}

Author accepted manuscript: published July 2012 in Journal of Peasant Studies 39 (3-4): 777-794

\begin{abstract}
Foreign investment in agricultural land acquisition in sub-Saharan Africa has been viewed primarily as driven by a set of linked 'crises': in financial capital markets; in security of energy and food supply; and in global environmental governance. This paper argues that a focus on the 'buyers' of land risks overlooking the dynamics that operate on the side of the land 'sellers'. Accordingly, the first part of the paper argues that it is important to view the current 'land grab' as the latest stage in a longer historical process of competition for control of land and other natural resources by different 'domestic' economic and political actors within African countries. While such struggles are often characterised as the 'state versus the peasantry', with the state acting on behalf of 'urban elites', the paper argues that processes of accumulation and associated enclosure of natural resources need to be examined more critically in specific contexts if the role and impact of foreign capital investment is to be understood. The second part of the paper seeks to identify in what ways questions of scale (in the sense of greater capital intensity) can be considered to be constraints to the development of African agriculture. Particularly, it considers to what extent do the production models most frequently mentioned in connection with foreign investment (large-scale mechanised farms and small-scale outgrower contract farming) respond to current productivity constraints. The paper argues that current debates about foreign investment in agricultural land underplay the importance of water resources needed to overcome production risks associated with irregular rainfall. Bringing the water dimension of land deals more clearly into focus is necessary if the scope for positive and negative impacts of new investment on existing land users is to be fully understood. The paper concludes by considering the implications of such challenges in the current context of foreign investment in agriculture in Africa.
\end{abstract}

\section{Introduction: the 'land grab' as a crisis narrative.}

The characterisation of recent rapid growth of foreign investment in agricultural land as a 'land grab' is consistent with the widespread perception that it is a manifestation of "a context of ecological, food and energy crises" (de Schutter 2011, 250). This suggests a sense of crisis that is pervasive, and Borras et al $(2011,209)$ also state "in many cases buyers and investors are simply preparing for the next global crisis". This generalised perception of crisis is understandable in the midst of the worst economic recession for seventy years, and will undoubtedly influence the behaviour of market actors. However, a discussion of the consequences of such market transactions demands also an understanding of the different facets of crisis to which they are a response. In particular, it is important to distinguish more proximate 'crises' from those that are rooted in a perception of longer-term problems of 'sustainability'. In this paper, however, I wish to question the usefulness of 'crisis' as a way of approaching the analysis of international land deals. I do this by considering the logic of foreign investment in agricultural land within processes of agrarian change within subSaharan Africa, where the majority of land deals have been located. Africa has, of course, been the subject of a series of crisis narratives - humanitarian, economic and ecological since independence from colonial rule, and in that sense the 'land grab' represents a certain continuity. However, whereas previous African crises were located in narratives about African society, the 'land grab' has so far focused attention mainly on the 'crises' motivating 
foreign 'buyers' of land, which I will first review briefly in order to ask: what is the nature of the crisis?

It seems reasonable to start by identifying the land deals as a response to an abrupt change in the behaviour of food commodity markets. The 2007-8 food price spike ended a three decade-long period of stable, but declining, agricultural commodity prices. Further, unlike the previous such episode in the 1970s, prices failed to fall back to their pre-spike levels and, after only two years at relatively lower levels, returned in late 2010 to close to the peak values seen in 2008. Agricultural commodity markets over the past five years have thus been characterised by both increasing and volatile prices (HPLE 2011). For these events to be understood as a trigger for foreign investment in agricultural land in developing countries, however, the key observation is that "the global food crisis of 2007-8 convinced many governments and private commodity buyers that international markets ...could not be trusted to provide a stable supply of food commodities..." (de Schutter 2011, 251). The growth in land deals are thus most clearly a response to a crisis of confidence in global food markets.

The question of why the behaviour of food commodity markets should have changed has been reviewed by the UN Committee on World Food Security. They note the Commodity Futures Modernization Act passed by the US Congress in 2000 allowed trading of financial derivatives based on commodities, notably the commodity index funds, reported to have increased fivefold in value in the three years prior to 2008 when they accounted for investments of US\$250billion (HPLE 2011, 25-6). However, the move of finance into agricultural commodity markets was itself promoted by a series of related crisis narratives. The chief of these was a concern with energy security arising from increasing oil prices after 2003, and interpreted as signalling an inability of new discoveries of oil reserves to meet growing demand (the 'peak oil' narrative). This prompted government subsidies for biofuel production in both the EU and the US, amounting to US\$10 billion in 2006 (FAO 2009a) and US $\$ 8$ billion in 2009 (IEA 2010) and generating a biofuel industry that consumes about $40 \%$ of US maize production and 66\% of EU vegetable oil production (HPLE 2011,32). The biofuel boom has been identified as a major factor causing food commodity prices to rise (FAO 2009a), but it has, in turn, been reinforced by other crisis narratives, notably that of climate change. This argues that the existing agricultural systems are threatened both by their dependence on increasingly costly fossil energy sources (particularly for nitrogen fertilizer), and by their vulnerability to changes in temperature and rainfall that will result from continued emissions of greenhouse gases. Of the latter about $12 \%$ of the global total are attributed to agriculture itself (FAO 2009b), rising to 30\% if changes in land use and deforestation are included (IPCC 2007). This analysis is nested within a broader narrative of an impending crisis in modern agriculture, which draws on well-documented negative impacts of input-intensive commercial agriculture on biodiversity and water quality as evidence for underlying unsustainability and imminent crisis (Weis 2010, Moore 2010). Thus a series of interlocking narratives have suggested both a crisis in the ability of existing agricultural systems to supply enough food, while also identifying agriculture as a solution to a crisis of energy security. While these broader perceptions of crisis have reinforced more immediate effects of price volatility of food commodity markets, it is important to note that policy responses, of which the land deals are one, have displayed a collapse in confidence in the efficiency of food and energy markets as the basis of reliable supply.

The UN Committee on World Food Security (CFS) observes that not all food markets were affected by the 2007-8 food price spike. In countries such as India and China, government food stocks were released and exports banned to counteract rises in domestic food prices. 
The CFS has proposed international coordination of food stocks held by governments, as well as tighter regulation of speculation in commodity markets (HPLE 2011). Whether such measures will be able to dispel the wider sense of agricultural crisis remains to be seen, but it is arguable that, at least in terms of understanding the impacts of the 'land grab' on rural poverty, viewing land deals primarily in terms of a conjuncture of crises in financial markets, energy and food supply, or governance of global trade, misses an important part of the story. In particular, this focus on the 'buyers' in land deals risks overlooking the dynamics that operate on the side of the land 'sellers'. This paper attempts to redress the balance. It does so by first sketching the enduring quest for agricultural modernisation by governments in subSaharan Africa and its significance for their current role as willing 'sellers' in land deals. The paper then argues that alternative visions for agriculture have been restricted by official narratives of rural society that tend to characterise rural society in terms of undifferentiated 'smallholders', and thus often fail to recognise the highly differentiated nature of rural communities generated by the dynamics of labour markets and local patterns of agricultural investment, particularly in the management of water for agriculture. The paper then considers the potential impacts of two models of foreign investment contemplated in land deals: largescale production and contract farming for small-scale producers. It argues that water remains a key blind spot in assessing land deal impacts, both because the need for irrigation to guarantee agricultural productivity is often only implicit in project proposals, but also because the new water infrastructure required by many - if not all - foreign investments in agricultural land will have potential effects - both positive and negative - far beyond the boundaries of the land included in the deals.

\section{The long quest for agricultural modernization in sub-Saharan Africa.}

Rural poverty in Africa has been blamed on inefficient 'backward' farming methods since colonial times and the search for a response through the introduction of modern farming methods has a similarly long history. In areas where impoverishment was most acute, notably in the colonies with significant European settlement and alienation of land, the period from the 1930s to the 1960s saw the wholesale reorganisation of African farming through a broadly consistent set of 'scientific' land use planning measures variously termed the Swynnerton Plan in Kenya, the Native Land Husbandry Act in Rhodesia and Betterment Planning in South Africa, and echoed in the picadas (rural roads) established to enable surveillance of forced cultivation of cotton in Mozambique. The principles which informed these schemes were: firstly to separate and consolidate zones of cultivation, residence and grazing; secondly to implement more productive technology, notably soil and water conservation and, where possible, mechanised (oxen or tractor) ploughing on arable areas, and improved grazing management; and thirdly better access to markets for agricultural produce via government-controlled marketing agencies or cooperatives. In more arid areas, such as the Sudan and the Sahel the modernisation project involved resettling farmers within areas served by large-scale irrigation infrastructure, such as the Gezira, the Office du Niger and the lower valley of the Senegal River. From the point of view of water management in agriculture, a sharp line was drawn between 'rainfed' and 'irrigated' agriculture. The modernisation project was underpinned by a basic assumption of government support for, and control of, input supply and output marketing, in large part reflecting colonial governments' perceptions of a strategic need to secure food production during successive crises of economic recession, wartime and postwar reconstruction that constituted the 1930s-60s. 
These assumptions of the developmental state continued to govern agricultural development under post-independence administrations, whether they focused on supporting a 'green revolution' among small-scale producers through subsidised supply of fertilizer, seed and pesticides, and state-run marketing agencies, or embarked on state-owned large-scale mechanised production, as in Mozambique and Ethiopia. Large-scale commercial plantations, with or without small-scale 'outgrowers' remained the model under both colonial and postindependence administrations for crops, such as sugar and tea, that require immediate processing. Large-scale European-owned farms in some instances, notably Zimbabwe, also provided working models for modernisation goals. By the late 1970s the pervasive failure to raise productivity in African agriculture meant the basic assumptions of state support for (and control of) agricultural production had become both the subject of critique from a variety of political perspectives (Shivji 1976, Lipton 1977, Bates 1981, Berg et al. 1982, Wuyts 1985), and also the object of reforms, most commonly referred to as 'structural adjustment programmes' (SAPs), imposed on many African governments by foreign funding agencies as a condition for loans to finance public budget deficits. Reforms followed a consistent formula including an immediate period of retrenchment of government employees and divestiture of government ownership in agriculture and agricultural services. The ensuing two decades involved low rates of public investment in agriculture (6-7 \% of agricultural GDP in Africa compared to $20 \%$ commonly encountered in developed economies) and a collapse in public expenditure on agricultural research. The same period saw a decline of about $50 \%$ in overseas development aid to agriculture between 1985 and 2000 (HPLE 2011, 29-30). Despite this SAP reduction in public funding for services to agriculture, the World Development Report 2008 (World Bank 2007) makes clear that in sub-Saharan Africa commercial agencies of input supply and output marketing have failed to provide an alternative. Further, it argues that the weakness of commercial input supply in Africa is due to the absence of 'complementary investment' in roads, irrigation, marketing infrastructure and financial services which underpin dynamic commercial inputs in Asia and Latin America (World Bank 2007, 150).

This raises the question of where such complementary investment is to come from, other than public funds More broadly, the failure of two decades of market deregulation to deliver a significant growth in aggregate agricultural output in much of sub-Saharan Africa suggests a need to reverse SAPs and re-instate government intervention as an element of increasing agricultural productivity. For many African governments, however, the impossibility of making such investments without recourse to foreign funding is an inescapable part of the context for land deals with foreign investors. Here it needs to be clear that it is not necessary to impute motives to specific governments or officials in relation to specific land deals. What is at issue here is to map a context in which a long-standing narrative of the failure of aggregate agricultural growth (i.e. at the level of the national economy) is understood in terms of a failure to modernise, whether in terms of small-scale 'green revolution' (high input use) farming or in terms of large-scale mechanised cultivation. Where public funds with which to pursue modernisation have been choked off by SAPs and subsequent restrictions on government expenditure, the appearance of foreign investors with proposals to establish 'modern' systems of production will hardly be unwelcome. The point here is not to defend the appropriateness of the modernisation narrative, with its consequences for designation of 'unused' or 'underutilised' areas under 'backward' and inefficient agriculture (de Schutter 2011, Li 2011), in understanding or improving agriculture in specific African contexts. Rather, it is to argue that its continuing prevalence among officials of both African governments and development funding agencies establishes a clear presumption in favour of seeking private investment in agriculture. As de Schutter (2011) argues, this reflects an absence of a credible alternative to 'modernisation' with which to guide agricultural 
investment. One reason why such an alternative may be difficult to identify is that discussion of agricultural development in Africa is often bound by social models that do not engage with actually-existing dynamics of social and agrarian change. In the next section I seek to identify aspects that appear to be important in analysing the impacts of particular patterns of agricultural investment.

\section{Dynamics of accumulation and agrarian change.}

Discussion of the political economy of foreign investment in agricultural land in Africa typically counterposes the interests of investors, allied with government officials and/or 'local elites' with interests vested in the land deal, against existing local land users or communities. It does indeed appear often the case that 'foreign' investment involves local private investment partners (cf Deininger 2011, 218). Also, government officials will inevitably be involved in authorising and registering the terms of the investment that usually involve a leasehold contract, often with a central government agency if the area involved is large. However, it is less often the case that existing land users are characterised as other than a homogeneous social group, uniformly affected by the proposed investment. In de Schutter's (2011) terms these are likely to be small-scale farmers who hold customary land rights through a history of generations of residence and land use in the area. I wish to argue that such a picture misses important elements of African rural economy that have a bearing on both the potential nature and outcome of foreign investment. In particular, rural people are engaged in labour markets, but in highly differentiated ways, with implications for both labour and capital investment in agriculture. On the one hand labour markets may mean a loss of 'household' labour from small-scale farms. On the other, alternative sources of income may explain the survival of otherwise 'non-viable' farms (see Cousins and Scoones 2010 for a critical discussion of 'viability') and, in the most positive scenarios, provide a source of investment to improve farm productivity. This linkage between 'off-farm' income and farming investment establishes an important capacity for private investment in agriculture, irrespective of any formal 'development' project or programme to promote it. This, in turn, raises the possibility of entrepreneurial small-scale agriculture. responsive to market opportunities and investing to achieve significant productivity growth. Finally, rural people are mobile, seeking better income opportunities not only in industrial and urban employment, but in other rural areas, which has consequences for the nature of rural 'communities'. I shall briefly elaborate on each of these in turn.

\section{Labour markets, off-farm income and agricultural investment.}

There is a paradox between the often-stated importance of agriculture as source of employment - typically above $60 \%$ of the working population in sub-Saharan African countries - and the low share of GDP - no more than a third, and typically a fifth - generated by agriculture (World Bank 2007, 340-1). The paradox is 'resolved' in the form of very low earnings from agricultural labour, and resort to non-agricultural work. Ellis (2000) suggested that non-farm income contributes 30-50 \% of rural income in much of Sub-Saharan Africa, rising to more than $80 \%$ in southern Africa. It needs to be acknowledged that this characteristic of rural incomes in Africa is not new, having historical antecedents in patterns of labour migration at least since the early twentieth century (Adams 1977, First 1983), but is now commonplace and documented by an extensive literature (Reardon 1997, 1998, Ellis 2000, Barrett et al. 2001, Ellis and Freeman 2005).

While this may be interpreted as a 'de-agrarianisation' of the rural economy (Bryceson 1999, 2002), it is also possible to consider it as integral to a re-ordering of the relationships of 
labour and capital within African farming in two important ways. Firstly, the engagement of labour from rural households in employment outside the household establishes an opportunity cost for labour on the family farm. Secondly, the level of income earned away from the family farm will determine whether "off-farm income" will compensate for the labour withdrawn from family farming. In making such assessments it is important to note that the timing of labour use in agriculture is critical. Thus, removal of labour may have critical impacts on farm productivity at certain, relatively short periods in the year, such as planting, weeding, or dry season clearing of fallowed land. Yet removal of that labour for a twelvemonth period may not generate earnings sufficient to compensate the loss in farm productivity.

Conversely, more remunerative off-farm employment may generate flows of capital that can not only hire replacement labour but invest in other inputs and equipment. Thus, off-farm income has been widely observed to constitute not only the principal source of agricultural investment in sub-Saharan Africa (Collier and Lal 1986, Bonnevie 1987, Reardon 1998, Lanjouw and Lanjouw 2001), but also a major mechanism for generating disparities of wealth within rural communities as a result of differences between individual households' capacity to achieve high earnings in off-farm work. This process is exemplified in Murton's (1999) detailed quantitative study of household investment in terrace construction for soil and water conservation in Machakos, Kenya. The corollary of the above observation is that local private investment in raising agricultural productivity can and does take place, although the capacity to do so is very unevenly distributed among the rural population. This remains the case, even where the technology for raising productivity is labour-intensive. This is clear not only from the Machakos terracing case, cited above, but also from the successful experience in the Sahel of promoting 'indigenous' labour-intensive methods (tassa and zwai pits) to bring degraded land back into production (Hassan 1996), or mulch application in Burkina Faso (Slingerland and Masdewel 1996), or green-manure and composting technologies in Kenya (Place et al. 2007). In these instances, higher off-farm income translates into greater ability to 'command' (hire) labour. The other means by which rural households may invest more labour to increase production is through control of land, by rental or sharecropping arrangements that involve major labour and possibly capital investments by tenants, as in the establishment of tree crop plantations (Amanor 2010; Kouame 2010), or in clearing forested areas for cultivation (Woodhouse et al. 2000). From the point of view of analysing the impacts of land deals, the above suggests rural communities will contain individuals with widely differing stakes in existing patterns of land and water use, raising the possibility that new forms of investment may offer opportunities to some while damaging the livelihoods of others. The presumption of a range of potentially conflicting impacts on members of rural communities must therefore underpin discussion of land deals.

\section{Market-responsive smallholder production.}

Investment in increased agricultural productivity can only be made in response to market demand, and there is evidence of investment in, and intensification of, agriculture where market access is good. This is most consistently evident in peri-urban zones of irrigated fruit and vegetable production, but also in rural areas where major transport corridors provide good access to urban markets, as in the case of small-scale irrigated horticultural production in Kajiado district, Kenya, on the main road between Mombasa and Nairobi (Southgate and Hulme 2000), or the several thousand hectares of furrow irrigation developed over the past two decades in the Penhalonga Hills, Mozambique, near the main road between Beira and Harare Bolding et al. 2010). 
The majority of such small-scale investments of capital and labour are to meet growing urban demand for high-value more perishable products. Such investments will not necessarily preclude food staples such as rice and maize, but the 'return on investment' is primarily generated by high-value crops. It is striking that improvement in water management is central to such strategies of agricultural development. As reviewed elsewhere (Woodhouse and Ganho 2011), water management forms an integral part of indigenous agricultural production systems throughout semi-arid and sub-humid rainfall zones that cover the majority of sub-Saharan Africa. This is so because of the strong seasonality of rainfall and the spatial variability of water distribution within the landscape. Whereas historic cultivation tended to emphasise adaptation to such variability by determining the timing and location of cultivation, for example through planting following a receding flood or in wet valley bottoms during the dry season, investment of capital and/or labour has allowed greater degrees of alteration of water flows through interception, diversion or storage to push back the spatial and temporal limits to cultivation, and hence expand the range of crops that may be grown.

Such water management constitutes investment of labour, capital and knowledge, and in many cases involves visible technology such as terraces, weirs, irrigation furrows and small pumpsets and boreholes. However, in many parts of rural Africa, its dispersed nature and its integration with rainfed cultivation, rather than separation in discrete blocks of 'irrigated farming', has tended to make it less visible to officials and technical staff trained to see 'irrigated' and 'rainfed' agriculture as separate production systems. Further, even where informal irrigation more closely approximates water control used in formal irrigation schemes (e.g. diversion of streams into canals), it tends to vary in extent from one year to the next according to water availability (Lankford 2004). As a consequence, although official statistics have since the 1980s recognised some 2 million ha of 'informal irrigation' in subSaharan Africa (excluding Madagascar) alongside 6 million ha of formal irrigation (FAO 2005), there can be little confidence that these reflect the significance of water management in African agriculture. This 'invisibility' of existing water management is further increased by the dearth of studies on how 'informal' water management strategies fit within broader African agricultural systems or livelihoods (Woodhouse 2012). These considerations highlight the importance of understanding existing production systems in terms of their use of resources such as water. In doing so, it is critical to appreciate the variation in water availability both spatially and temporally, suggesting particular attention to the way cultivation on different sites and in different seasons may be interdependent within an overall production system. Unless the distinct, interlocking elements of existing land use are identified, there is a risk that significant aspects of existing water management will be rendered invisible.

\section{Mobility of rural population}

Discussion of migration of people in sub-Saharan Africa has tended to focus on circular patterns of migration, particularly between agricultural and mining areas, or migration from rural areas to towns and cities. Much less attention has been paid to migration between rural areas. Yet, the key role of migrants recurs in empirical studies of agricultural development. The development of plantations of cocoa in West Africa (Hill 1963), the growth of commercial groundnut production in the Gambia (Robertson 1987), and the more recent growth of commercial pineapple growing in Cote d'Ivoire (Kouame 2010) all featured large inflows of migrants who cultivated under a variety of rental and sharecropping arrangements with existing landholders. Similarly, case studies of exploitation of water resources for agriculture in Mali (Woodhouse et al. 2000) and Kenya (Southgate and Hulme 2000), and Mozambique (Bolding et al. 2010) all highlight the role of migrants, not just as suppliers of 
labour, but also of farming expertise. In some instances of rapid agricultural development (e.g. in parts of Kajiado District in Kenya's Maasailand) migrants had become the majority of the rural population. Such population inflows into areas with favourable agricultural conditions may be associated with growing competition for land and increasingly commoditised transactions in land in the form of rental, sharecropping or sale agreements (Woodhouse 2003, Benjaminsen and Sjaastad 2004, Peters and Kambewa 2007). Here it is important to underline that such tendencies towards commoditised access to land do not require formal land titles, but may be observed within customary land tenure systems (Chimhowu and Woodhouse 2006). The shifting terms of land access are a manifestation of broader change in the rural society in which they are embedded (Colin and Woodhouse 2010), and Pauline Peters argues that evidence of growing competition for land "calls into serious question the image of relatively open, negotiable, and adaptive customary systems of landholding and land use and, instead, reveals processes of exclusion, deepening social divisions, and class formation" (Peters 2009, 1319).

In summarising the above observations, it is important to note that I have focussed on instances of agrarian change that have not been initiated or mediated by externally-funded development 'projects'. Such processes of rural change, although evidently susceptible to modification by political and economic initiatives of the state, are present and active whether or not development agencies intervene. Thus foreign investment projects cannot be assumed to take place within rural areas made up of smallholders dependent on household labour and non-commodified access to land via customary tenure. A more appropriate set of assumptions would embrace the likelihood that rural communities will contain households with significant engagement in the rural and non-rural labour market, highly differentiated according to wealth and rights to land. Where the area is well-connected to markets, local investment in intensive agriculture, particularly involving water management, may be expected, and a significant part of the population may be migrants from elsewhere whose access to land may be defined by sharecropping, rental or other monetary arrangements with local holders of customary land rights. Such assumptions would have to be tested in specific rural contexts, but they imply that any simple counterposing of 'state' and 'urban elites' to 'communities' is unhelpful in identifying the impacts of foreign agricultural investment. In the following section I consider how models of agricultural production under foreign investment land deals are likely to respond to the productivity constraint posed by risks of low and/or uncertain rainfall.

\section{Investment, productivity and the water constraint in African agriculture.}

One of two models of farming structure feature most commonly in discussion of land deals: large-scale mechanised production units, and small-scale 'outgrowers' supplying a central processing and/or marketing facility. Both models promise improvement in market access, a key constraint evidenced by FAO's (2009a) finding in Kenya, Zambia and Mozambique that less than half of maize-growing households regularly sell their crop. This is partly a reflection of low levels of marketable surplus, but also of the significant disadvantages of smaller producers, such as lack of adequate storage or financial resources to enable them to delay sales after harvest, ensuring that they receive the lowest prices from traders. Yet similar dynamics of bargaining power may apply in outgrower schemes as in other markets in which small-scale producers have little choice but to sell to the first buyer they encounter, raising questions about the regulation of the terms of outgrower contracts (Little and Watts 1994). 
If the need for investment to achieve economies of scale in marketing is widely accepted, the desirability of increases in scale of agricultural production is highly contested. One the one hand, advocates of small-scale production units argue that small farms are more labourintensive and hence more 'efficient', producing greater yield per unit area as well as greater employment (Lipton 1977, Griffin et al. 2002). On the other hand, critics argue higher land productivity on smaller farms may be illusory, reflecting denser population in more fertile areas (Dyer 2004), or that it arises not from greater efficiency, but from greater selfexploitation, of family labour (Byres 2004). This latter point is illustrated by a World Bank study comparing production costs in Brazil, Thailand and four African countries, which observed:

'The competitiveness of Africa's producers at the farm level derives mainly from very low returns to labor (reflecting the absence of alternative employment opportunities in rural areas) and limited use of purchased inputs (which results in significant soil nutrient mining). .... at current productivity levels and farm size, agriculture is economically impoverishing and technically unsustainable.' (World Bank 2009, 5). The significance of labour markets, highlighted earlier, is also suggested in the same study, for data from Nigeria:

'when family labour is assigned a value equivalent to $60 \%$ of the wage rate for hired labour, small-scale cassava production with traditional labour-intensive production practices and resulting low yields looks much less attractive compared with medium and large-scale production' (World Bank 2009, 81).

It hardly needs saying that (over)-exploitation of family labour is heavily conditioned by intra-family relationships of age and gender (Jones 1986, Kouame 2010).

Employment effects of large-scale and small-scale units of production are also disputed. Much writing on the subject has argued that more employment (and hence wider reduction in poverty) is generated by supporting the productivity growth of small farms (Mellor 1976, Lipton 1977, de Schutter 2011). However, recent empirical work in Africa gives grounds to question this view. Introduction of higher quality standards for vegetable exports to the EU from the Niayes area of Senegal (Maertens and Swinnnen 2009) caused production to be restructured away from smallholders towards larger-scale production units integrated with processing and packing facilities. However, extreme poverty fell by half in the population studied, since the larger units employed many people who had no access to land, effectively too poor to be smallholders. Different, but not inconsistent, results from a study of rural labour markets in Mozambique (Cramer et al. 2008) showed that wage labour was both prevalent and important to livelihoods, particularly among poorer women, and that wage rates were higher on larger farms than on smaller ones. This does not provide conclusive support for the proposition that larger farms will generate more employment than small-scale cultivation (Sender and Johnson 2004), but it certainly underlines the importance of understanding rural communities as differentiated by wealth and access to land, so that smallholders farming their own land may not be the "poorest of the poor".

It is also evident that debate about the employment impact of large-scale farms must differentiate between the type of agriculture being practiced. In large-scale grain farming, of the kind practiced in Brazil and Argentina, there seems little doubt that there are few jobs (albeit highly-paid ones). In contrast, commercial fruit and vegetable production requires relatively high labour inputs, not only in field operations, but also in processing and packing, typically generating large numbers of jobs. The question, then, is whether these jobs can constitute 'decent work'. Tania Li, in a previous JPS Forum on the Land Grab (Li 2011) provides evidence that large-scale investment in oil palm plantations in South-East Asia 
operate on the principle of recruiting from an impoverished labour pool with little access to land of their own, and hence more willing to accept low wages. She argues that, since commercial considerations do not lead companies to pay anything other than poverty wages, state intervention is needed to regulate employment conditions if immiseration and poverty are to be avoided. I return to consider the implications of this argument in the concluding section of the paper.

The preceding paragraphs suggest that simple arguments in favour of large or small production units will not suffice to predict impacts of land deals on labour productivity or employment. In practice, such impacts are likely to be highly context-specific. However, a focus on labour productivity in agriculture shifts the farm size/productivity debate in important ways. It indicates that levels of investment ('scale' of production) need to be differentiated from 'size' of land area farmed. For example, the comparison of small-scale cultivation arising from land reform in Brazil with underutilised latifundia landholdings will not necessarily produce the same conclusions as the comparison of the land reform farms with highly capitalised intensive grain cultivation on large-scale mechanised farms on the cerrado. Nor should it be assumed, moreover, that productivity is dependent on land ownership. Deininger and Byerlee (2011) observe that the largest scale agricultural producers in Argentina own neither land nor farm machinery, but are constituted by farm management companies that lease land from landowners and contract machinery services from specialist operators. Conversely, however, it needs to be recognised that increasing farm scale also confronts constraints. Operating costs of farm machinery will be substantially higher in subSaharan Africa, as supply chains for spare parts are longer and equipment is more vulnerable to spend time out of service (World Bank 2009, 85). Even on commercial mechanised farms in 1980s Zimbabwe, where operators had long experience of local conditions, farm machinery costs were reckoned to be over $20 \%$ higher than for similar farms in the United States (Stanning 1983). The evidence reviewed above suggests that scale of production unit in foreign investment projects cannot be used as a simple indicator of productivity or employment impacts. I now turn to consider questions of scale in relation to investment in water management.

As stated above, water management to reduce risk can be seen to play a central role in African agriculture, not only in the structuring of long-established patterns of land use, but also in the way local producers make new investments of labour and capital to improve agricultural productivity. Scale is significant, in that water management is seldom possible to achieve in a way that is entirely contained within a single small-scale unit. Generally, interception, diversion or storage of water creates downstream effects or may place demands on upstream land users. It thus places particular priority on larger-scale intervention and investment, even if this is a matter of many coordinated small-scale actions (e.g. terracing, irrigation furrows, drainage ditches) on neighbouring farm units. The remainder of this section focuses on the implications of large-scale agricultural investment for developing water management.

I have argued earlier that, although water management has often been a focus of farmers' own investments in agricultural intensification this may often not register within formal planning systems. The dispersal of water management investments among small-scale units, their often seasonal nature, and their deployment of techniques unfamiliar to those trained to see water management only in terms of formal irrigation projects, means that they are not easily visible to administrative and planning agencies. This problem may be compounded by the way small-scale water use has been addressed within water legislation, including - 
paradoxically - by its relatively favourable treatment within recent reforms. For example, South Africa's 1998 National Water Act stipulates that water allocation is to be governed through the issue of water use permits to individual water users. However, in certain areas (usually ex-'bantustan' territories reserved for African settlement), the requirement for individual water licences has been waived in favour of a 'general authorisation' for smallscale water use. Similarly, under Mozambique's water law of 1991 all water use must be registered and licensed except 'common use' (usos comuns), which has priority over all other water use. Common use is defined as water used by rural households for domestic needs, watering livestock and irrigation of an area of up to one hectare, as long as this does not use mechanical devices. While such uses have priority over commercial use, for example in large-scale agriculture, the fact that they are not registered or quantified means that they are invisible to the planning process. This has prompted van Koppen et al. $(2009,28)$ to comment "small-scale water uses are tolerated, as long as any new water uptake remains insignificant and....as long as the marginalised remain marginalised, there is no problem"

This potential blind spot for existing water use is matched by the lack of explicit mention of water requirements in many land deals. A few land deal contracts in the public domain concern proposed projects that deal explicitly with expansion of irrigation in semi-arid areas, such as the agreement by Libya to finance the expansion of irrigation infrastructure to allow cultivation of a further 100,000 ha in Mali's Office du Niger scheme (GRAIN 2009, Cotula $2011,36)$. Otherwise, it is striking how little mention is made of water management in discussion of agricultural land deals in Africa. Mann and Smaller $(2010,6)$ are among the few commentators who draw attention to this, arguing access to water resources is a key goal of land deals: "...a critical motivation in the current trend towards large-scale land acquisitions is the water factor."

The World Bank (2010) discusses land deals only in terms of rainfed agriculture, as does an earlier report (World Bank 2009) emphasising the large potential for expansion of cultivation in Africa's sub-humid 'guinea savannah'. However, the latter does concede:

'Irrigation may not be as critical in the Guinea Savannah as in other more arid production environments, but the potential contribution of irrigation to African agriculture should not be underestimated. Commercial farmers in southern Africa have long known that even a single pre-planting irrigation can make an enormous difference in enabling timely planting and ensuring that crops get off to a vigorous start, which can significantly affect eventual yields and reduce risks.' (World Bank 2009, 119).

This acknowledgement signals a weakness in conventional approaches to agricultural water management, namely the sharp division between 'rainfed' and 'irrigated' agriculture. In practice, agriculture in much of Africa's savannas may require something in between. The potential benefits of some intermediary form of water management cannot be judged by commonly cited aggregate indicators, such as total annual rainfall, or length of growing period. This is because, as stated above, the unreliability of rainfall extends to drought periods during the growing season, making supplementary irrigation or some other form of water management essential to avoid water shortages at critical moments of crop development. The IIASA study (Fischer et al. 2002) on which the World Bank (2010) draws for its assessments of amounts of 'available land' for agricultural expansion includes an assessment of the impact of irrigation on both land 'availability' and potential production. In the case of maize, irrigation is estimated to raise potential harvests by $49 \%$ and $39 \%$ above that of high-input rainfed production in East and West African regions respectively. For southern Africa, the equivalent figure is a three-fold increase (332\%) in maize harvests. For 
South America the potential increase was estimated at only 29\% (Fischer et al. 2002, table 5.19). It does not follow that irrigation of maize in sub-Saharan Africa is always a financially rational strategy, but these estimates underline the point that agricultural potential is likely to be highly influenced by water management.

De Schutter (2011) has observed that foreign investor interest is focused on fertile and high rainfall, irrigated or irrigable areas, and it is hard to escape the conclusion that investors African land deals are not expecting to be subject to the vagaries of African rainfall. A review of crops proposed for cultivation in land deals in Africa (Woodhouse and Ganho 2011) strongly indicates that these will need irrigation, even where this has not been stated in the published information. This is because projects involve crops with high year-round water requirements (sugar cane, bananas), or because they involve dry-season cultivation (wheat, vegetable, fruit), or because the projected yields are only obtainable under optimum (including moisture) conditions (e.g. jatropha, cf Schut et al. 2010). Large-scale land-deals, therefore, imply large-scale use of water resources. This need not be negative in a region routinely observed to suffer from under-using its water resources (FAO 2005). Investment in dams for water storage can make more water available through the dry season, with positive impacts on agricultural output beyond the immediate project land. For example, a 3000 ha commercial banana plantation established in 2010 in northern Mozambique is to be irrigated using water from a 60 million cubic metre capacity reservoir behind a dam constructed upstream on the Monapo river. The significance of this water storage can be appreciated by comparing it to the capacity of 4 million cubic metres for the dam which supplies the nearby provincial capital, Nampula, with a population of a little less than half a million people. As a consequence of the new dam, the dry season river flow between the reservoir and the banana plantation will be higher and more regular than previously, offering a potential new resource for other local economic activity. One possible use for such a resource would be to provide supplemental irrigation to protect small-scale producers from the worst effects of dought periods. To do so would require additional infrastructure, but could radically widen the potential distribution of benefits from the scheme. Whether such potential wider benefits will be realised will depend on recognition of the important 'public good' benefits that such investment may provide. In particular, larger investments offer possibilities of water management on a larger scale and for many more people than existing small-scale investment has thus far achieved. To say this is not to underestimate the political challenges such a strategy would confront, not least as a consequence of increasing competition over land that had become more productive as a result of improved access to water (Woodhouse 2003).

It is evident that such a strategy would also need to avoid damage to the myriad forms of existing water management by small-scale agricultural producers and people engaged in fishing, livestock-rearing and other water using enterprises. It was, indeed, the failure to identify and avoid such impacts that was the hallmark of failed state-sponsored water infrastructure projects in the 1970s (Diemer and Vincent 1992). Here, as in the assessment of water management needs of crops in African savannas, there is a need to question whether conventional approaches to measuring land and water use are adequate. Just as I observed above the problem of 'visibility' of existing patterns of water use, so it is important to assess potential impacts at the times and places where they are most critical. This is exemplified by the Malibya project, noted above, to extend the area of the existing Office du Niger irrigation scheme in Mali. GRAIN (2009) reported that the project funders were negotiating for the project to have priority access to irrigation when river flows are lowest. However, to do so would potentially jeopardise existing producers' most valuable crop (cool season fruit and vegetables) thus undermining the financial viability of the system as a whole. Bues (2011) 
has documented the imposition of priority water access for foreign-own floriculture farms on canal systems in Ethiopia, disrupting institutional arrangements for water sharing among existing small-scale irrigators. Van der Zaag et al. (2010) have also shown how the impact of a 30,000ha irrigated project on the Limpopo, in Mozambique, could only be fully assessed by estimating the probability of water flow in the river during the driest months of the year. In each of these cases the critical impacts of projects on water availability during the time of greatest scarcity cannot be assessed simply by the land area occupied, nor by total rainfall, nor total water consumption. Only an appreciation of existing water use, particularly during the dry season, and likely annual variability in water supply, would enable an assessment of impact.

To identify opportunities for broad-based improvement in water availability, whether or not it includes large-scale units of agricultural production, and avoid damage to the range of existing water users clearly goes beyond the remit of investors in the land deals that have formed part of the current 'land grab'. Most obviously it demands a role for the state in defining and enforcing a public interest as part of land deal contracts.

\section{FDI and agricultural modernisation.}

In this paper I have argued that the focus in 'land grab' discussion on international investors, and the crisis narratives that motivate their investments, risks distracting attention from the dynamic character of the African rural societies in which such land deals will be implemented. In particular, an acknowledgement of rural areas as connected to markets, and particularly labour markets - both local and distant - leads to an understanding of African rural communities as significantly differentiated in terms of wealth and land rights. Such differences may be translated in various ways to differences of political identity and power, defined in a variety of terms such as ethnicity, lineage, gender, age, or length of settlement in the area. I have highlighted the range of ingenuity and skill with which African agricultural producers manage land and water, expanding production, investing in new technology or moving to new areas where market opportunities warrant it. Rather than a tradition-bound society of small farmers, it may be more useful to envisage African rural communities as being made up of a variety of more or less mobile populations, probing the frontiers of the political economy in which they live. Yet, as Peters (2009) sets out in detail, these are processes creating winners and losers, and greater inequality within rural societies, with the impoverishment of some linked to the enrichment of others. It is these processes that narratives of a homogeneous rural society of 'smallholder farmers' allow policymakers to ignore. Equally, it is important to acknowledge that winners and losers will also be created even where 'public goods' can be maximised from large-scale investment in agricultural water management.

In calling for a re-thinking of land-grabbing, de Schutter (2011) questions the assumption that large-scale, export-oriented agriculture is the inevitable direction which agriculture must take in developing countries, with only the capacity to regulate contract design and implementation as concerns for successful social outcomes. While accepting this point, in this paper I have suggested a need to go further. An understanding of rural communities as differentiated, mobile, changing, as outlined here, raises questions about what other assumptions might be being made about patterns of rural development in the absence of large-scale investment that would permit 'access to land and water...democratized for the local farming communities' (de Schutter 2011, 250). In this paper I have argued that the advantages of small-scale farming, whether with respect to employment, productivity, or 
poverty-reduction are by no means established. Type of crop, effects on labour productivity and wage rates, as well as the generation of public goods are all aspects of large-scale investment that need context-specific evaluation. The question of improved water management is not only central to the challenge to improve the productivity of agricultural work, but also highlights the social and political dimensions of any interventions to address it. Moreover, even where small-scale production is preferred, it is likely that, if improved labour productivity, and reduced production risks through better water control are to be achieved for more than a minority of better-off smallholders, then large-scale investment by the state or state-regulated private investment will be needed. While this suggests a central role of state intervention, it is important to avoid reducing this to a matter of technical or financial capacity. The dynamics of increasing inequality in African rural society outlined above demand, above all, political leadership in defining what values and goals shall set the parameters for investment. This will need to negotiate inter alia the role that markets, customary hierarchy, gender, age and ethnicity play in determining the rights of individuals to property and income, as well as the public accountability to be expected of government officials. Without such political leadership, it seems likely that modernising investment, whether in small-scale or large-scale production, will exacerbate the tensions already present within rural societies.

\section{References}

Adams, A. 1977. Le long voyage des gens du fleuve. Paris: Maspero

Amanor, K. 2010. Land sales, family values and commodification: the dynamics of agrarian change in southeastern Ghana. Africa, 80 (1), 104-125

Barrett, C., Reardon, T. and Webb, P. 2001. Nonfarm income diversification and household livelihood strategies in rural Africa: concepts, dynamics, and policy implications. Food Policy, 26, 315-331.

Bates, R. 1981. Markets and states in tropical Africa. Berkeley: University of California Press.

Benjaminsen, T. and Sjaastad, E. 2002. Race for the prize: land transactions and rent appropriation in the Malian cotton zone. European Journal of Development Research, 14(2), 129-152

Berg, E., Amoako, K. and Guesten, R. 1982. Accelerated development in sub-Saharan Africa: an agenda for action. Washington DC: The World Bank.

Bolding, A., Post Uiterweer, N. and Schippers, J. 2010. The fluid nature of hydraulic property: a case study of Mukudu, Maira and Penha Longa irrigation furrows in the upper Revue river, Manica District. In: P. van der Zaag (ed) What role of law in promoting and protecting the productive uses of water by smallholder farmers in Mozambique? CGIAR Challenge Programme on Water and Food, pp.105-136

Bonnevie, H. 1987. Migration and Malformation. Case Studies from Zimbabwe. Copenhagen: Centre for Development Research.

Borras, S., Hall, R., Scoones, I., White, B. and Wolford, W. 2011. Towards a better understanding of global land grabbing: an editorial introduction. Journal of Peasant Studies, 38 (2), 209-216

Bryceson, D. 1999. African rural labour, income diversification and livelihood approaches: a long-term development perspective. Review of African Political Economy. 80, 171-89.

Bryceson, D. 2002. The scramble in Africa: reorienting rural livelihoods. World Development, 30 (5), 725-739 
Bues, A. 2011. Agriculture foreign direct investment and water rights: an institutional analysis from Ethiopia. Presented at the Conference on Global Land Grabbing 6-8 April, 2011, Institute of Development Studies, University of Sussex, UK.

Byres, T. J., ed. 2004. Redistributive Land Reform Today, special issue of Journal of Agrarian Change, 4 (1-2).

Chimhowu A. and Woodhouse P. 2006. Customary vs private property rights? Dynamics and trajectories of vernacular land markets in sub-Saharan Africa. Journal of Agrarian Change, $6(3), 346-371$

Colin, J-P. and Woodhouse, P. 2010. Introduction: interpreting land markets in Africa. Africa, $80(1), 1-13$

Collier, P. and Lal, D. 1986. Labor and poverty in Kenya 1900-1980. Oxford: Clarendon Press.

Cotula, L. 2011. Land deals in Africa: what is in the contracts? London: International Institute for Environment and Development.

Cousins, B. and Scoones, I. 2010. Contested paradigms of 'viability' in redistributive land reform: perspectives from southern Africa. Journal of Peasant Studies, 37 (1), 31-66.

Cramer, C., Oya, C. and Sender, J. 2008. Lifting the blinkers: a new view of power diversity and poverty in Mozambican labour markets. Journal of Modern African Studies, 46 (3), 361-392

Deininger, K. 2011. Challenges posed by the new wave of farmland investment. Journal of Peasant Studies, 38 (2), 217-247.

Deininger, K. and Byerlee, D. 2011. The Rise of large farms in land abundant countries. Do they have a future? Policy Research Working Paper 5588. Washington DC: The World Bank.

Diemer, G. and Vincent, L. 1992. Irrigation in Africa: the failure of collective memory and collective understanding. Development Policy Review, 10, 131-154.

De Schutter, O. 2011. How not to think of land-grabbing: three critiques of large-scale investments in farmland. Journal of Peasant Studies, 38 (2), 249-279.

Dyer, G. 2004. 'Redistributive land reform: no April rose. The poverty of Berry and Cline and GKI on the inverse relationship. Journal of Agrarian Change, 4 (1\&2), 45-72

FAO 2005. Irrigation in Africa in figures - Aquastat Survey 2005. Rome: Food and Agriculture Organisation of the UN.

FAO, 2009a. The State of Agricultural Commodity Markets 2009. Rome: Food and Agriculture Organisation of the United Nations.

FAO, 2009b. Low Greenhouse Gas Agriculture. Mitigation and Adaptation Potential of Sustainable Farming Systems. Rome: Food and Agriculture Organisation of the United Nations.

Fischer, G., van Velthuizen, H., Shah, M. and Nachtergaele, F. 2002. Global Agroecological Assessment for Agriculture in the 21st Century: Methodology and Results. Laxenberg, Austria: International Institute for Applied Systems Analysis.

Ellis, F. 2000. Rural livelihoods and diversity in developing countries. Oxford: Oxford University Press.

Ellis, F. and Freeman, A. eds. 2005. Rural Livelihoods and Poverty Reduction London: Routledge.

First, R. 1983. Black Gold. Brighton: Harvester.

GRAIN 2009 Rice land grabs undermine food sovereignty in Africa. http://www.mailarchive.com/sustainablelorgbiofuel@ sustainablelists.org/msg73860 accessed 15/4/2010

Griffin, K., Khan A. and Ickowitz, A. 2002. Poverty and the Distribution of Land. Journal of Agrarian Change, 2 (3): 279-330. 
Hassan, A. 1996. Improved traditional planting pits in the Tahoua Department (Niger): an example of rapid adoption by farmers. In: C. Reij, I. Scoones, and C. Toulmin, eds.

Sustaining the soil. Indigenous soil and water conservation in Africa. London: Earthscan. pp.56-61

Hill, P. 1963. The Migrant Cocoa Farmers of Southern Ghana. Cambridge: Cambridge University Press.

HPLE 2011. Price volatility and food security. A report by the High Level Panel of Experts on Food Security and Nutrition. July 2011. Rome: United Nations Committee on World Food Security.

IEA 2010. World Energy Outlook 2010. Paris: International Energy Agency.

IPCC (2007) Climate Change 2007: The physical science basis. Contribution of Working Group I to the Fourth Assessment Report of the Intergovernmental Panel on Climate Change. Cambridge: Cambridge University Press.

Jones, C. 1986. Intra-household bargaining in response to the introduction of new crops: A case study from North Cameroon. In: J. L. Moock ed. Understanding Africa's rural households and farming systems, Boulder, CO: Westview Press. pp. 105-23.

Kouame, G. 2010 Land Markets and Land Conflicts: intra-family and socio-political dimensions in the Abure case, Cote d'Ivoire. Africa, 80 (1), 126-146

Lanjouw, J. and Lanjouw, P. 2001. The rural non-farm sector: issues and evidence from developing countries. Agricultural Economics 26, 1-23

Lankford, B. 2004. Resource-centred thinking in river basins; should we revoke the crop water requirement approach to irrigation planning? Agricultural Water Management, 68, 33-46

Li, T. M. 2011. Centering labor in the land grab debate. Journal of Peasant Studies, 38 (2), 281-298.

Lipton, M. 1977. Why poor people stay poor. London: Temple Smith.

Little, P. and Watts, M. 1994. Life under contract: contract farming, agrarian restructuring and flexible accumulation. Madison: University of Wisconsin Press.

Maertens, M. and Swinnen, J. 2009. Trade, standards and poverty: evidence from Senegal. World Development, 37 (1), 161-178.

Mann, H. and Smaller, C. 2010. Foreign Land Purchases for Agriculture: what impact on sustainable development? Sustainable Development Innovation Brief No 8. New York: United Nations Department of Economic and Social Affairs.

Mellor, J. 1976. The new economics of growth. Ithaca, New York: Cornell University Press

Murton, J. 1999. Population growth and poverty in Machakos District, Kenya. Geographical Journal, 165(1), 37-46.

Peters, P. 2009. Challenges in land tenure and land reform in Africa: anthropological contributions. World Development, 37 (8), 1317-1325.

Peters P. and Kambewa, D. 2007. Social conflicts over access and transfer of land in Malawi and their implications for new land policy. Journal of Modern African Studies, 45, $447-$ 472.

Place, F., Adato, M., Hebinck, P. and Omosa, M. 2007. Impacts of agroforestry-based soil fertility replenishment practices on the poor in Western Kenya. In: M. Adato and R. Meinzen-Dick eds. Agricultural Research, Livelihoods and Poverty. Baltimore: Johns Hopkins University Press, pp.149-197.

Reardon, T. 1997. Using evidence of household income diversification to inform study of the rural non-farm labor market in Africa. World Development, 25(5), 735-747.

Reardon, T. 1998. Rural non-farm income in developing countries. In: The State of Food and Agriculture 1998. Rome: Food and Agriculture Organization of the United Nations. 
Robertson A. 1987. The dynamics of productive relationships. African share contracts in comparative perspective. Cambridge : Cambridge University Press.

Schut, M., Slingerland, M. and Locke, A. 2010. Biofuel developments in Mozambique. Update and analysis of policy, potential and reality. Energy Policy, 38, 5151-5165.

Sender, J. and Johnson, D. 2004. Searching for a Weapon of Mass Production in Rural Africa: Unconvincing Arguments for Land Reform. Journal of Agrarian Change, 4 (1\&2), 142-164.

Shivji, I. 1976. Class struggles in Tanzania. London: Heinemann

Slingerland, M. and Masdewel, M. 1996. Mulching on the Central Plateau of Burkina Faso. In: C. Reij, I. Scoones, and C. Toulmin. eds. Sustaining the soil. Indigenous soil and water conservation in Africa. London: Earthscan, pp.85-89.

Southgate, C. and Hulme D. 2000. Uncommon Property: the scramble for wetland in southern Kenya. In: P. Woodhouse, H. Bernstein, and D. Hulme. African Enclosures? Social dynamics of wetlands in drylands. Oxford: James Currey, pp.73-118.

Stanning, J. 1983. Production costs of farming in Zimbabwe. Zimbabwe Agricultural Journal, 80, 57-60.

Van der Zaag, P., Juizo, D., Vilanculos, A., Bolding, A. and Post Uiterweer, N. 2010. Does the Limpopo river basin have sufficient water for massive irrigation in the plains of Mozambique? In: $\mathrm{P}$. van der Zaag ed. What role of law in promoting and protecting the productive uses of water by smallholder farmers in Mozambique? CGIAR Challenge Programme on Water and Food, pp.41-49

Van Koppen, B., Sally, H., Aliber, M., Cousins, B. and Tapela, B. 2009. Water resources management, rural redress and agrarian reform. Development Planning Division Working Paper Series No 7. Halfway House: Development Bank of Southern Africa

Woodhouse, P. 2003. African Enclosures: a default mode of development. World Development, $31(10), 1719-1733$.

Woodhouse, P. 2012. Water in African agronomy. In: J. Sumberg, and J. Thompson, eds. Contested agronomy: agricultural research in a changing world. London: Earthscan, pp.102-115.

Woodhouse, P., Trench P. and Tessougué M. 2000. A very decentralised development. In: P. Woodhouse, H. Bernstein, and D. Hulme. African Enclosures? Social dynamics of wetlands in drylands. Oxford: James Currey, pp.29-72.

Woodhouse, P. and Ganho, A-S. 2011. Is Water the hidden agenda of agricultural land acquisition in sub-Saharan Africa? International Conference on Global Land Grabbing 68 April 2011, Institute of Development Studies, University of Sussex, UK.

World Bank 2007. World Development Report 2008: agriculture for development. Washington DC: World Bank.

World Bank 2009. Awakening Africa's sleeping giant. Prospects for commercial agriculture in the Guinea Savannah Zone and beyond. Washington DC: The World Bank.

World Bank 2010. Rising global interest in farmland. Can it yield sustainable and equitable benefits? Washington DC: The World Bank.

Wuyts, M. 1985. Money, planning and rural transformation in Mozambique. Journal of Development Studies, 22 (1), 180-207. 